\title{
LINEA ALBA COLLAGEN ASSESSMENT IN MORBIDLY OBESE PATIENTS
}

\author{
Avaliação de colágeno da linha alba em pacientes obesos mórbidos
}

João Vicente Machado GROSSI, Felipe Fernandes NICOLA, Ivan Alberto ZEPEDA, Martina BECKER, Eduardo Neubarth TRINDADE, Vinicius Von DIEMEN, Leandro Totti CAVAZZOLA, Manoel Roberto Maciel TRINDADE

From the Hospital de Clínicas de Porto Alegre, Universidade Federal do Rio Grande do Sul e Departamento Médico Legal, Instituto Geral de Perícias (Hospital de Clinicas, Federal University of Rio Grande do Sul and Department of Legal Medicine, Instituto Geral de Perícias), Porto Alegre, RS, Brazil.

HEADINGS - Anastomosis, Roux-en-Y. Bariatric surgery. Gastric bypass. Stenosis.
ABSTRACT - Background: The evaluation of collagen in the abdominal wall has been increasingly studied because of the relevance on collagen in the healing process after laparotomy. Aim: To evaluate the amount of collagen in the linea alba of patients undergoing laparotomic bariatric surgery and comparing with non-obese cadavers. Methods: Were evaluated 88 samples of aponeurosis from abdominal linea alba of 44 obese patients (obesity group) and 44 nonobese cadavers (control group). The samples were collected in 2013 and 2104, and were sorted according to age (18-30,31-45 and 46-60), gender, BMI, waist and cervical circumference, and subcutaneous tissue thickness. Material for biopsy was collected from the supraumbilical region of the linea alba for immunohistochemical analysis differentiating collagen type 1 and type 3 and the 1/3 ratio. Image-Pro Plus pixel counting software was used to measure the amount of collagen. Results: The obesity group evidenced mean age $44.11 \pm 9.90$ years; $18-30$ age group had three (6.8\%) obese individuals; $31-45$ had 22 (50\%) and 46-60 had 19 (43.1\%). Females were present in $81.8 \%(\mathrm{n}=36) ; \mathrm{BMI}\left(\mathrm{kg} / \mathrm{m}^{2}\right)$ was $48.81 \pm 6.5$; waist circumference $(\mathrm{cm})$ was 136.761 \pm 13.55 ; subcutaneous tissue thickness $(\mathrm{cm}) 4.873 \pm 0.916$. Considering age groups, gender and $\mathrm{BMI}$, there were statistical differences in all tests when compared with the cadavers. Conclusion: The amount of collagen in the linea alba above the umbilical region in the morbidly obese patients was smaller than in the non-obese cadavers in the same age group.

\section{Correspondence:}

Joao Vicente Machado Grossi

E-mail: jvicentegrossi@gmail.com

Financial source: FIPE-Foundation incentive to Research - Analysis imumo-chemistry and histologic analysis

Conflicts of interest: none

Received for publication: 16/02/2016 Accepted for publication: 10/05/2016

DESCRITORES: Obesidade. Colágeno. Linha alba.
RESUMO - Racional: A avaliação do colágeno na parede abdominal é cada vez mais estudada, em virtude da relevância dele no processo cicatricial após laparotomia. Objetivo: Avaliar a quantidade de colágeno na linha alba de pacientes submetidos à cirurgia bariátrica e compará-la com a de cadáveres não-obesos. Método: Foram avaliados dois grupos com total de 88 amostras da aponeurose da linha alba abdominal, divididas em 44 de pacientes obesos (grupo obesidade) com indicação de cirurgia bariátrica e 44 de cadáveres não-obesos (grupo controle). As amostras foram retiradas da linha alba abdominal no período de 2013 a 2014 e inicialmente foram separadas conforme faixas etárias (1830, 31-45 e 46-60), gênero, medidas de IMC, circunferência abdominal e cervical e espessura do subcutâneo do indivíduo. Foi coletado material para biópsia da linha alba supraumbilical para análise imunoistoquímica, diferenciando o colágeno tipo I e lll e sua relação de tipo I/III. Utilizou-se o programa de contagem de pixels Image-Pro Plus ${ }^{\oplus}$, que mensurou a quantidade do colágeno. Resultados: $\bigcirc$ grupo obesidade teve idade $44,11 \pm 9,90$ anos, Na faixa etária de $18-30$ anos foram incluídos três $(6,8 \%)$ obesos; na de 31-45 anos 22 (50\%) e na de 46-60 anos 19 (43,1\%). O gênero feminino apresentou predomínio, com $36(81,8 \%)$ pacientes. O IMC $\left(\mathrm{kg} / \mathrm{m}^{2}\right)$ foi de $48,81 \pm 6,5$; a circunferência abdominal (cm) foi de 136,761 $\pm 13,55$; a espessura do subcutâneo $(\mathrm{cm})$ foi de $4,873 \pm 0,916$. A quantidade de

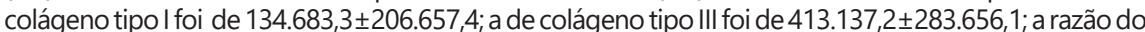
colágeno tipo I/III foi 0,419 $\pm 0,636$. Considerando-se faixas de idade, gênero e IMC, foram constatadas diferenças estatísticas em todas as análises quando comparadas com às dos cadáveres. Conclusão: Os obesos mórbidos apresentaram quantidade de colágeno na linha alba supraumbilical menor que a do grupo controle de cadáveres não-obesos na mesma faixa etária.

\section{INTRODUCTION}

(cc) BY This is an open-access article distributed under the terms of the Creative Commons Attribution License.
$\mathrm{T}$ he repair of abdominal wall hernias remains the most common operation for the general surgeon. For a long time, numerous studies have been developed to search for causes and best method of treatment ${ }^{1,20}$. The causes of failure in bringing the abdominal walls together are important research topics ${ }^{12,13}$. The incidence of abdominal wall defects in obese patients is high, reaching $30 \%$ after laparotomy. Thus, to identify the factors that may influence the degree of strength and resistance of the abdominal wall in patients with high body mass index - above $35 \mathrm{~kg} / \mathrm{m}^{2}$ - and possible postoperative hernia becomes critical to the surgeon ${ }^{8}$. The replacement of the structural matrix of the abdominal wall from type I collagen by type III has been described as a cause of hernias in the inguinal region ${ }^{9,18}$. However, to date, the amount and stratifications have not been established in obese patients and their stratifications in the supra umbilical region.

This study aims to identify the predominant type of collagen in the anterior wall of patients undergoing bariatric surgery, comparing with non-obese cadavers. 


\section{METHODS}

Linea alba samples from patients with indication to bariatric surgery and from non-obese cadavers from the Forensic Medicine Department of Porto Alegre were analyzed in the Hospital de Clinicas de Porto Alegre, Porto Alegre, RS, Brazil. The protocol was approved by the Group for Research and Graduate Studies of the Porto Alegre University Hospital and by the Ethics Committee of the Hospital de Clínicas, under protocol number 269331/2013. The study was also approved by the Scientific Division of the Forensic Department of Porto Alegre.

The study sample consisted of two groups. The number of individuals in each group was stipulated by sample calculation based on the study of Fachinelli, which established the need to measure a minimum difference of 80 pixels between total collagen in obese patients and controls, with a standard deviation of 131 pixels. Considering a statistical power of $80 \%$ and a significance level of $\alpha=0.05$, at least 44 subjects in each group were needed, totaling 88 individuals to be analyzed.

The obesity group consisted of 44 patients who underwent gastric bypass surgery with Roux-en-Y in Hospital de Clínicas de Porto Alegre from March 2013 to December 2014. Inclusion criteria were: patients in Digestive Surgery Clinic of the Hospital de Clínicas de Porto Alegre that agreed to the informed consent (IC); patients diagnosed with morbid obesity and to whom bariatric surgery was recommended (BMI>40 or $\mathrm{BMI}>35$ with co-morbidities); older than 18 and younger than 60 years. The exclusion criteria were: patients who underwent prior surgery at linea alba supraumbilical; with lesions or deformities in the front wall; with degenerative diseases; with Marfan syndrome, osteogenisis imperfecta and Ehlers-Danlos syndrome.

The non-obese group consisted of 44 cadavers from the Forensics Department of Porto Alegre. Inclusion criteria were: individuals with up to $12 \mathrm{~h}$ of death; older than 18 and younger than 60; with BMI of $18 \mathrm{~kg} / \mathrm{m}^{2}$ and less than 25 $\mathrm{kg} / \mathrm{m}^{2}$. The exclusion criteria were: patients who underwent prior surgery at linea alba supraumbilical; with lesions or deformities in the front wall; with degenerative diseases; with Marfan syndrome, Osteogenisis imperfecta and EhlersDanlos syndrome.

The study consisted in the analysis of the collagen in the anterior abdominal wall by laparotomy incision during the procedure with gastrointestinal bypass in Roux-en-Y.

Sample collection of the linea alba sized $1 \times 1 \mathrm{~cm}$ was performed at the incision site of the surgical procedure in the midline $5 \mathrm{~cm}$ from the angle of the xiphoid process. The sample was stored in formalin solution for fixation and underwent subsequent histochemical study. Immunohistochemistry was performed for staining. Each sample studied underwent two analyses: one slide was used for immunohistochemical staining to detect collagen type I and another slide was stained for collagen type III. A total of 176 slides were stained. ${ }^{7}$

Quantitative and qualitative assessment of collagen types I and III was performed by immunohistochemistry, using the polyclonal anti-collagen type I (PA1-85317) and polyclonal anti-collagen type III (PA1-85314) antibodies. Was used an imaging system composed of an Olympus microscope with a coupled video camera. The video signal was scanned in 32-bit on a personal computer with a resolution of 1280 (horizontal) by 960 (vertical) pixels and 24 million colors. The software used was Q-Capture Pro 5.1. Ten fields were scanned with a 400 times magnification per slide in a total of 1760 digital images in TIFF file extension format. The scanned images were analyzed using the Application Program Image Pro-Plus, version 3.1 (Media Cybernetics, Silverspring, USA).

\section{Statistical analysis}

Mann-Whitney $U$ test was used for quantitative variables with asymmetrical distribution; for continuous variables with normal distribution, Student's t test was employed. The tests with $p<0.05$ were considered statistically significant. SPSS (Statistical Package for Social Science) version 22.0 was used for data analysis.

RESULTS

The study was conducted until all samples for each group were acquired. There were no surgical complications in the group of obese patients due to the collection of tissue sample. The descriptive analysis of each group was presented as mean \pm standard deviation, with the respective percentages

The initial measurement for sample characterization shows an age profile of the obesity group with mean and standard deviation, in years, of $44.11 \pm 9.9$. There was a predominance of female, with the presence of $36(81.8 \%)$ individuals with weight in $\mathrm{kg}, 128.7 \pm 23.02$, totaling a BMI $\left(\mathrm{kg} / \mathrm{m}^{2}\right)$ of $48.89 \pm 6.50$. Excess weight (weight prior to surgery - corresponding to $\mathrm{BMI}=25$ its height) was $62.89 \pm 19.13 \mathrm{~kg}$, respectively. The non-obese cadavers showed a male predominance, with 36 (81.8\%) cases, mean age and standard deviation of $32.7 \pm 7.05$, weighing $69.96 \pm 6.82$ and $\mathrm{BMI} 23.98 \pm 1.17$.

With regard to comorbidities in the obesity group during the preoperative examination, only two (4.5\%) patients were considered healthy, while 42 (95.5\%) out of $44 \mathrm{had}$ at least one comorbidity, especially systemic arterial hypertension in 38 (86.4\%) patients, diabetes mellitus in $18(40.9 \%)$ and smoking history. With regard to smoking, $10(22.72 \%)$ patients said they had ceased smoking more than two years earlier, two (4.54\%) patients had ceased smoking from a year up to three months prior to surgery and 32 (72.72\%) denied ever smoking. Among patients with a history of chronic lung diseases, including asthma, only five $(11.4 \%)$ were users of nasal corticosteroids at a low dose (<100 mcg a day), and 19 (43.2\%) patients had symptoms of sleep apnea. Hypothyroidism was present in nine (20.5\%) patients, and the number of pregnancies had mean and standard deviation of $1.48 \pm 1.83$ per patient. In the control group, patients with a history of comorbidities, including smoking and pregnancy, were excluded.

Anthropometric measurements were used to differentiate the distribution pattern of weight and fat in both groups. The obesity group showed statistically significant measurements in all features, including height with mean and standard deviation of $170.62 \pm 7.49$ vs $162.36 \pm 7.64$, in $\mathrm{cm}, \mathrm{p}<0.01$ when compared to the non-obese cadavers. Followed by the $\mathrm{BMI}$ analysis, with rates of $48.89 \pm 6,50$ versus 23.98 $\pm 1.17 \mathrm{~kg} / \mathrm{m}^{2}, \mathrm{p}<0.01$. Abdominal circumference measured in $\mathrm{cm}(136.76 \pm 13.55$ vs $80.06 \pm 6.82)$, neck circumference (42.57 \pm 4.20 vs $36.57 \pm 2.05)$, arm circumference ( $41.66 \pm 4.89$ vs $27.33 \pm 3.62)$, waist circumference $(121.45 \pm 12.16$ vs $78.41 \pm 6.34)$ and hip circumference $(139.33 \pm 15.58$ vs $90.26 \pm 7.72)$ had a statistically significant difference of $p<0.01$ in the obesity and in the non-obese cadavers, respectively. The thickness of subcutaneous fat at the biopsy site for the linea alba in the obesity group presented mean and standard deviation (in $\mathrm{cm}$ ) of $4.87 \pm 0.91$ vs $1.94 \pm 0.61$ in the non-obese cadavers, $\mathrm{p}=0.007$.

The collagen count was done through the Image-Pro Pus ${ }^{\circledR}$ program in photographs obtained by microscopy $400 x$, which captures the image and transforms it into pixels, 1200 by sample field. The obesity group had a mean and standard deviation of $134,683.3 \pm 206,657.4$ pixels in collagen type I samples and $413,137.2 \pm 283,656.1$ pixels in collagen type III samples and $0.419 \pm 0.636$ was the average ratio of collagen type I/III. The control group (non-obese 
group) had an average quantity \pm standard deviation of $1,587,378.8 \pm 719,527.5$ pixels for type I collagen, an average of $630,629.1 \pm 396,242$ for collagen type III and the ratio of collagen type I/III was $27.49 \pm 8.96$ pixels. When compared using the Mann-Whitney $U$ test, this showed a statistically significant difference $(p<0.001)$ in samples of collagen type $\mathrm{III}$ and the ratio of collagens type I/III and also $\mathrm{p}=0.03$ in the collagen type I. When was compared the obesity and non-obese cadavers, the obesity group had a lower count of collagen type I in three samples; using the Mann-Whitney $U$ test, this showed a statistically significant difference $p<0.001$ in samples of collagen type III and a ratio of I/III and also $p=0.03$ in collagen type I (Figure 1 ).

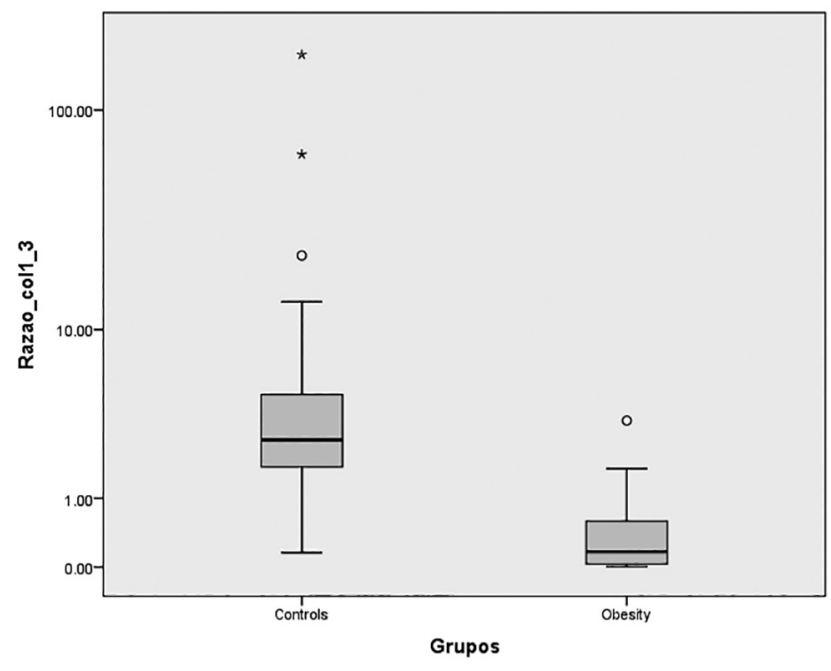

Mann-Whitney U-test for independent, $\mathrm{p}<0.001$

FIGURE1 - Comparison of obesity vs non-obese cadavers groups in the ratio of collagen type I / III: samples shows significant difference with an increased amount of collagen in the control group compared to obese

The analysis of collagen per se followed as an attempt to elucidate whether there were differences between samples from patients with the same gender. Comparing the amount of collagen in women, was used the $U$ Mann-Whitney test for independent samples with type III collagen, and the ratio of collagen type I/III presented statistically significant differences, with the highest score in the non-obese group $(p<0.001)$ and collagen type $I, p=0.011$. In males, there were statistically significant differences only in the collagen type $\mathrm{III}$ and the ratio of collagen type I/III, with $\mathrm{p}<0.01$; there was no statistical difference in type I collagen count, with $\mathrm{p}=0.068$ (Figure 2).

Was chosen to divide the samples by age groups for detailed analysis of the collagen. In the first group, with ages ranging from 18 to 30 , there were three (6.8\%) patients in the obesity group vs 21 (47.7\%) in the non-obese cadavers. In the group of 31-45 years old there were 22 (50\%) vs 21 $(47.7 \%)$. In the group 46-60 years, 19 (43.2\%) were identified vs two (4.5\%) in the non-obese cadavers. Using the MannWhitney $\mathrm{U}$ test in the analysis of collagen type III and the ratio between I/III in the $18-30$ group, there is a statistically significant difference, with $p=0.06$, but not in type I collagen, with $p=0.965$. The same analysis was performed for the other groups, presenting difference in the 31-45 group for collagen type III and the ratio between types I/III, but no statistical difference in the type I collagen analysis, $p=0.052$. Among older subjects (46-60 years) the same finding about the amount of collagen in the obesity group compared to the cadavers remained with respect to type III collagen and the ratio $\mathrm{I} / \mathrm{III}$ with $\mathrm{p}=0.023$ and $\mathrm{p}=0.042$, respectively, but there was no evident difference in type I collagen count, with $p=0.188$. Comorbidities of the patients in the obesity group showed no statistically significant difference when compared to the amounts of type I collagen, type III and the ratio I/III, considering the presence of hypertension, diabetes mellitus, pulmonary obstructive disease and sleep apnea, hypothyroidism, smoking and number of pregnancies (Figure 3).

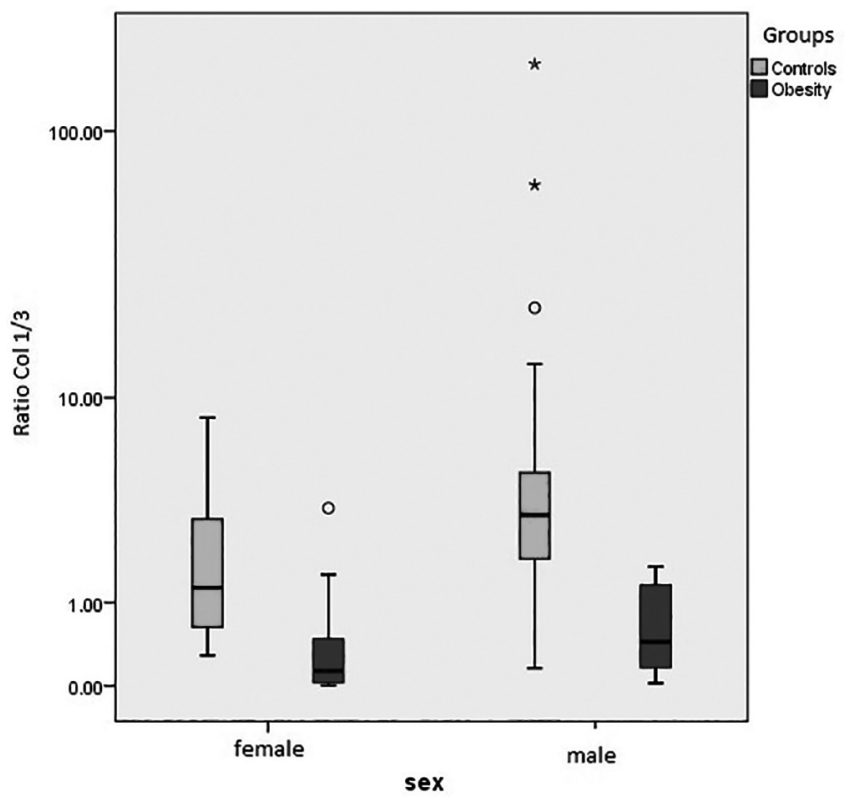

FIGURE 2 - Comparison of obesity and non-obese cadavers groups in the ratio of collagen type I/III distributed by gender

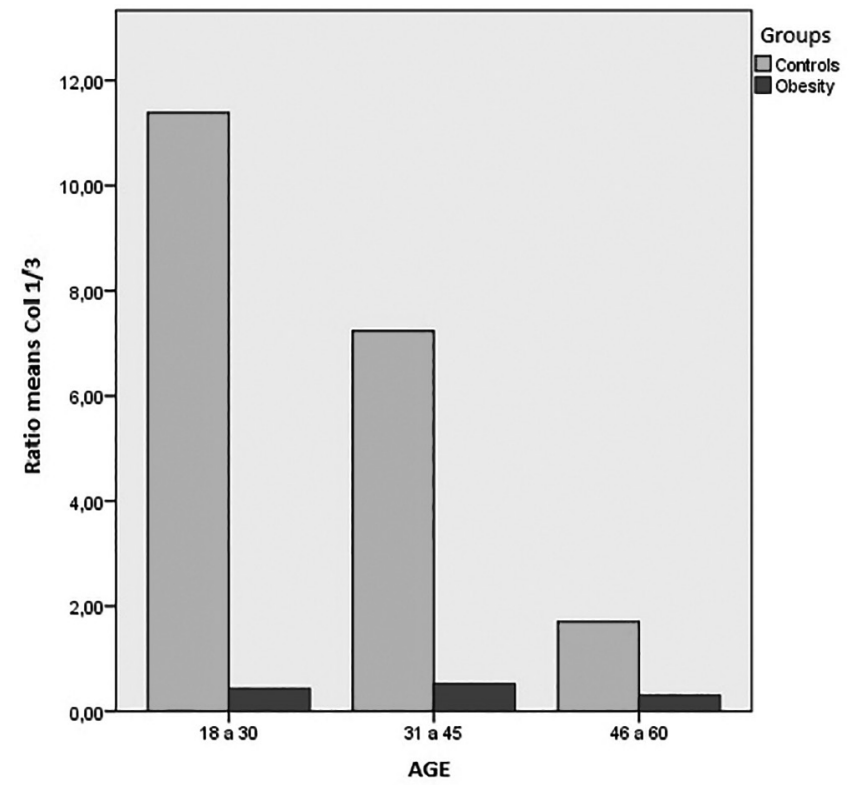

FIGURE 3 - Comparison of age groups according to the ratio of collagen type I/III

\section{DISCUSSION}

Collagen continues to be studied to evaluate suitable laparotomy closure and repair of abdominal wall hernias. The study shows a decrease in the total amount and, in particular, a decrease in type I and III collagen and the ratio of type I/ III, which may point to a risk factor for wall closure defects, even in situations such as laparoscopy and robotic surgeries.

For patients considered as high risk, due to high BMI, female gender or elder age, closing alternatives have been 
considered, with reinforcements or techniques such as the use of meshes and, although still under development, stem cells as a reinforcement in special situations such as in the case of patients submitted to bariatric surgery that develop incisional hernia, which can reach $30 \%$ when compared to the non-obese population, where it is up to $15 \%{ }^{7}$.

In the process of wound closure, there is an increase of collagen type III that develops into type I, with stronger density and structure due to the type of cellular connection. It is therefore important to monitor the obese patient when he/she has a deficit in the amount of collagen and there is still a weight loss goal set for a relatively short period (two years), reaching more than $50 \%$ of the excess weight ${ }^{6,17,24}$.

Several studies s $^{511,14,25}$ use obesity as an independent risk factor for the development of early and late postoperative complications. Linear regression models show that obesity changes the wound healing process and raises surgical site infection rates. Furthermore, the thickness of the subcutaneous fat appears to influence these rates, supporting our findings that there is a statistically significant difference in the decrease of collagen and increased thickness of the subcutaneous tissue in obese patients as compared to non-obese cadavers.

The study in male cadavers was divided into two broad age groups (18-30 years and $31-60$ years), with similar results in collagen composition in linea alba in the supra and infra umbilical regions, compared with the results of the groups in this study. The decrease in the amount of collagen type I and III was observed in the older age group, reinforcing the theory of weakness in the abdominal wall over the years, even in patients that were not distributed according to risk factors ${ }^{4}$. Even in studies that point to a previously existent incisional hernia, age is classified as a risk factor for adverse events in the postoperative period ${ }^{3,16}$.

The characteristics of each gender influence the arrangement of anisotropic fiber tensile forces in different directions along the linea alba, and even the healing phase after midline incision. The female gender was described as a risk factor in a study with over 4000 patients, which also included the BMI and thickness of the subcutaneous tissue. In the samples described here, there was a significant difference in the amount of collagen type I and type III and in the ratio I/III when compared to the cases in males and even between obese and non-obese from the same gender, leading to an increased risk of defects in the synthesis of the abdominal wall in morbidly obese women, which is a part of the growing world population ${ }^{14}$.

These considerations reflect a group of high-risk for defects on the wall after a procedure, requiring the search for alternatives to minimize the negative effects. Alternatives like the use of preventive meshes have been under discussion for several years, with favorable and deleterious outcomes from several studies $7,15,23,24$,

In response to alternatives for proper closure of the abdominal wall in high-risk patients for incisional hernia, ways to provide substrate for the synthesis of the wall should be investigated, which could point to the advent of mesenchymal stem cells. However, there are still no results indicating that they may play a role in safe repair of the abdominal wall or their preventive use ${ }^{21}$. Some limitations of the study can be better evaluated in randomized clinical trials to assess long-term follow-up of patients with the development or not of postoperatively incisional hernias.

\section{CONCLUSION}

Obese patients had an amount of collagen in the umbilical linea alba smaller than the non-obese group when compared to non-obese cadavers in the same age group.
REFERENCES

1. Abdalla RZ, Garcia RB, da Costa RI, Abdalla BM. Treatment of mid-line abdominal wall hernias with the use of endo-stapler for mid-line closure. Arq Bras Cir Dig. 2013 Nov-Dec;26(4):335-7.

2. Augenstein VA, Colavita PD, Wormer BA, Walters AL, Bradley JF, Lincourt $A E$, Horton J, Heniford BT. CeDAR: Carolinas Equation for Determining Associated Risks Journal of the Am ColSurg.2015;221(4):65-6.DOI:http:// dx.doi.org/10.1016/j.jamcollsurg.2015.07.145

3. Caglià $P$, Tracia A, Borzì L, Amodeo L, Tracia L, Veroux M, Amodeo C. Incisional hernia in the elderly: risk factors and clinical considerations. Int J Surg. 2014;12 Suppl 2:S164-9.

4. Calvi EN, Nahas FX, Barbosa MV, Calil JA, Ihara SS, Juliano Y, Ferreira LM. Collagen fibers in the rectus abdominis muscle of cadavers of different age. Hernia. 2014 Aug;18(4):527-33.

5. Castilho TJ, Campos AC, Mello EV. Effect of omega-3 fatty acid in the healing process of colonic anastomosis in rats. Arq Bras Cir Dig. 2015 Nov-Dec;28(4):258-61.

6. Culbertson EJ, Xing L, Wen Y, Franz MG. Loss of mechanical strain impairs abdominalwallfibroblastproliferation, orientation, and collagencontraction function. Surgery. 2011 Sep;150(3):410-7.

7. Curro G, CentorrinoT, LowV, Sarra G, Navarra G. Long-term outcomewith the prophylactic use of polypropylene mesh in morbidly obese patients undergoing biliopancreatic diversion. Obes Surg. 2012 Feb;22(2):279-82. doi: 10.1007/s11695-011-0486-y.

8. DeBord JR. The historical development of prosthetics in hernia surgery. Surg Clin North Am. 1998 Dec;78(6):973-1006, vi.

9. Engelsman AF, van Dam GM, van der Mei HC, Busscher HJ, Ploeg RJ. In vivo evaluation of bacterial infection involving morphologically different surgical meshes. Ann Surg. 2010 Jan;251(1):133-7.

10. FachinelliA, TrindadeMRM.Avaliaçãoqualitativaequantitativadocolágeno total, tipo I e III da linha alba em pacientes portadores de hérnia de parede abdominal anterior. Langenbecks Arch Surg. 2007;392(4):459-64.

11. FischerJP,WinkJD, TuggleCT,NelsonJA, KovachSJ.Woundriskassessment in ventral hernia repair: generation and internal validation of a risk stratificationsystemusing theACS-NSQIP. Hernia.2015Feb;19(1):103-11.

12. GonçalvesRdeO, deMoraeseSilvaE, LopesFilhoGdeJ.Immunohistochemical evaluation offibrillarcomponents oftheextracellularmatrix oftransversalis fascia and anterior abdominal rectus sheath in men with inguinal hernia. Rev Col Bras Cir. 2014 Jan-Feb;41(1):23-9.

13. GreviousMA, CohenM,Jean-PierreF,Herrmann GE. The use of prosthetics inabdominal wall reconstruction. ClinPlastSurg.2006 Apr;33(2):181-97,v.

14. Itatsu K, Yokoyama Y, Sugawara G, Kubota H, Tojima Y, Kurumiya Y, Kono $\mathrm{H}$, Yamamoto $\mathrm{H}$, Ando M, Nagino M. Incidence of and risk factors for incisionalherniaafterabdominalsurgery.BrJSurg.2014Oct;101(11):1439-47

15. KlingeU, Zheng H, SiZ, SchumpelickV, Bhardwaj RS, Muys L, Klosterhalfen $B$. Expression of the extracellular matrix proteins collagen I, collagen III and fibronectin and matrix metalloproteinase-1 and -13 in the skin of patients with inguinal hernia Eur Surg Res. 1999;31(6):480-90.

16. Konerding MA, Bohn M, Wolloscheck T, Batke B, Holste JL, Wohlert S, Trzewik J, Förstemann T, Hartung C. Maximum forces acting on the abdominal wall: experimental validation of a theoretical modeling in a human cadaver study. Med Eng Phys. 2011 Jul;33(6):789-92.

17. Krpata DM, Criss CN, Gao Y, Sadava EE, Anderson JM, Novitsky YW, Rosen MJ. Effects of weight reduction surgery on the abdominal wall fascia wound healing process. J Surg Res. 2013 Sep;184(1):78-83.

18. Meyer AL, Berger E, Monteiro Jr O, Alonso PA, Stavale JN, Gonçalves MP. Quantitative and qualitative analysis of collagen types in the fascia transversalis of inguinal hernia patients. Arq Gastroenterol. 2007 JulSep;44(3):230-4.

19. Mutwali IM. Incisional Hernia: Risk Factors, Incidence, Pathogenesis, Prevention and Complications. Sch J App Med Sci. 2014; 2(4E):1491-7.

20. Novitsky YW, Harrell AG, Hope WW, Kercher KW, Heniford BT. Meshes in hernia repair. Surg Technol Int. 2007;16:123-7.

21. Petter-Puchner AH, Fortelny RH, Gruber-Blum S, Redl H, Dietz U. The future of stem cell therapy in hernia and abdominal wall repair. Hernia. 2015 Feb;19(1):25-31.

22. Ramos FZ, Signore FL, Ribas-Filho JM, Thiele ES, Dobrowolski S, Salles Jr GS, Fonseca VRCD, Baroncello J. Perfil epidemiológico de pacientes com hérnia incisional. ABCD Arq Bras Cir Dig 2007;20(4):230-3

23. Scozzari G, Zanini M, Cravero F, Passera R, Rebecchi F, Morino M. High incidence of trocar site hernia after laparoscopic or robotic Roux-en-Y gastric bypass. Surg Endosc. 2014 Oct;28(10):2890-8.

24. Trindade EN, Trindade MR. The use of mesh and collagen in incisional hernias. Hernia. 2007 Feb;11(1):83-4.

25. Veljkovic R, Protic M, Gluhovic A, Potic Z, Milosevic Z, Stojadinovic A. Prospective clinical trial of factors predicting the early development of incisional hernia after midline laparotomy. J Am Coll Surg. 2010 Feb;210(2):210-9.

26. Wolwacz Jr I, Trindade MRM, Cerski CT. O colágeno em fáscia transversal de pacientes com hérnia inguinal direta submetidos à videolaparoscopia. Acta Cir Bras. 2003;18(3):196-202. 